\title{
Radiation doses due to the natural radioactivity in Pakistan marble
}

\author{
M. TUFAIL*, M. IQBAL*, S.M. MIRZA*
}

(Manuscrit rȩ̧u le 7 décembre 1999, révisé le 12 avril 2000, accepté le 18 avril 2000)

\begin{abstract}
In view of its high potential for containing large amounts of radioactive materials and due to its wide-spread use as construction and facing material worldwide, radiation doses received from the marble used in dwellings have heen determined. As a first step, specific activity measurements were made using a NaI(Tl) gamma ray spectrometer using the spectrum stripping technique. For the samples studied, the average values of specific activities for ${ }^{226} \mathrm{Ra}$, ${ }^{232} \mathrm{Th}$ and ${ }^{40} \mathrm{~K}$ have been found to be 27,26 and $58 \mathrm{Bg} \mathrm{kg}^{-1}$ respectively. The mesh-adaptive, volume-integral method based code INGRE (Mirza et al., 1991) gave calculated values of the dose equivalent rates inside the standard room (Tufail et al., 1994) due to ${ }^{226} \mathrm{Ra},{ }^{232} \mathrm{Th}$ and ${ }^{40} \mathrm{~K}$; these were found to lie between 5-77, 12-52 and 1-11 nGy $\mathrm{h}^{-1}$ respectively. The values of wholebody dose equivalent rates have been found to lie in the $27-108 \mathrm{nGy} \mathrm{h}^{-1}$ range. As these values are below internationally accepted maximum permissible values, therefore marble available in Pakistan can safely be used in dwellings as a construction material.
\end{abstract}

RÉSUMÉ Les doses de rayonnement dues à la radioactivité naturelle contenue dans le marbre du Pakistan.

Le marbre possède la propriété de contenir de grandes quantités de matières radioactives; dans le monde entier, il est utilisé comme matériau de construction et de parement; c'est pourquoi, nous avons déterminé les doses de rayonnement venant du marbre employé dans le bâtiment. Nous avons d'abord mesuré l'activité spécifique au moyen d'un spectromètre gamma de NaI (TI) utilisant la technique de dépouillement de spectre. Dans le cas des échantillons étudiés, nous avons trouvé des activités spécifiques ${ }^{226} \mathrm{Ra}^{232} \mathrm{Th}$ et ${ }^{40} \mathrm{~K}$ de 27,26 et $58 \mathrm{~Bq} \mathrm{~kg}^{-1}$, respectivement. La méthode à maille adaptable et à intégration volumique, fondée sur le code INGRE (Mirza et al., 1991), donnait les valeurs des débits de dose équivalente dans la pièce de référence (Tufail et al., 1994), dues au ${ }^{226} \mathrm{Ra}$, au ${ }^{232} \mathrm{Th}$ et au ${ }^{40} \mathrm{~K}$; nous avons trouvé des valeurs comprises entre 5 et 77,12 et 52,1 et $11 \mathrm{nGy} \mathrm{h}{ }^{-1}$ respectivement. Les valeurs des débits de dose équivalente corps-entier se placent entre $27 \mathrm{nGy} \mathrm{h}^{-1}$ et $108 \mathrm{nGy} \mathrm{h}^{-1}$. Ces valeurs de dose équivalente se trouvent au-dessous des maxima admissibles au niveau international : on peut employer sans risque le marbre du Pakistan dans le bâtiment, comme matériau de construction. 


\section{Introduction}

Recent times have seen increasing awareness of the hazards associated with natural and man-made sources of radiation. The primordial radionuclides impart as much as $80 \%$ of the total natural effective dose equivalent for the population (Jamil et al., 1997; NRPB, 1981; UNSCEAR, 1988). Among the natural sources, ${ }^{238} \mathrm{U}$ and ${ }^{232} \mathrm{Th}$ series and ${ }^{40} \mathrm{~K}$ have been found to contribute more than $50 \%$ of the total external dose to the general public (UNSCEAR, 1988). Since, in current civilizations, most time is spent indoors, efforts have been concentrated on the assessment of radiation dose due to natural radioactivity in building materials (Aslam and Ahmad, 1997). Many international organizations including the International commission on radiological protection (ICRP, 1993), the World health organization (WHO, 1993), the International atomic energy agency (IAEA, 1994), etc., have set limits on the radionuclide content of materials used in dwellings. The use of materials with abnormally high levels of radioactivity for construction purposes has been banned (Mustapha et al., 1997). As the part of this worldwide effort, the measurements of specific activities of various building materials have been carried out in many countries (UNSCEAR, 1988) including Pakistan (Tufail et al., 1992a-c).

Among the various building materials, marble has found wide usage mainly due to its variety of attractive colours and soft texture. In geology, any metamorphic rock composed of crystalline aggregate of calcite and/or dolomite is termed marble. Commercially, any calcareous and/or dolomite rock capable of giving a fine polished surface and suitable for decorative and structural purposes, is termed as marble (Ahmad, 1969). Being of sedimentary origin, it has potential of containing amounts of radioactive materials leached out from strata rich in uranium and thorium (Shah, 1977).

In this work, the total effective dose rates for an individual in a standard, marblefinished room of dimensions $4 \mathrm{~m} \times 5 \mathrm{~m} \times 2.8 \mathrm{~m}$ with wall thickness $20 \mathrm{~cm}$ (Tufail et al., 1994) has been determined. This includes both the experimental measurements of the radioactive contents of the various types of marbles available in Pakistan and the calculations of external dose due to ${ }^{40} \mathrm{~K},{ }^{226} \mathrm{Ra}$ and ${ }^{232} \mathrm{Th}$ using volume integral based mesh-adaptive methodology (Mirza et al., 1991). The details of the experimental work and the experimentally determined values with calculated overall dose rates, internal and external hazard indices, etc. are presented in this paper.

\section{Experimental details}

\subsection{Sample collection and preparation}

In Pakistan, marble extracted from the mountains of the Salt Range, Northern Areas and from Baluchistan Province, is transported to marble factories in various cities. 
The samples used in the present study were collected from different factories located in Islamabad, the capital city of Pakistan. About half a kilogram of each sample was collected and marked.

The material was brought to the sample preparation facility, which is far from the low-level gamma ray activity measuring facility. The samples were properly catalogued, washed and dried in the sun. They were crushed and ground. The powder was dried at $110^{\circ} \mathrm{C}$ in a furnace for complete removal of moisture and then sealed in radon-impermeable plastic containers. The containers were similar to those containing reference material obtained from the IAEA ${ }^{1}$. The volume of each sample container was $213.13 \mathrm{~cm}^{3}$ including screw caps. The powder was sufficiently compacted to make the density of the experimental samples and that of the IAEA reference samples nearly equal. Both the reference material and the marble sample containers were stored for more than 40 days to achieve secular equilibrium between radium and radon (Tufail, 1992c).

\subsection{Detection system and its calibration}

For the measurement of natural radioactivity levels in the marble samples, a NaI(T1) based gamma ray spectrometer was used with a lead shield of a length $20.5 \mathrm{~cm}$, a diameter $15.7 \mathrm{~cm}$ and a thickness $3.7 \mathrm{~cm}$. A particular portion of the spectrum of the mixture of the RG set (IAEA, 1995) containing the $1460.8,1764.5$ and $2614.6 \mathrm{keV}$ energy peaks was obtained by adjusting amplifier gain and ADC offset of multi-channel analyser (MCA). The energy calibration of the spectrometer was carried out using these peaks. It may be noted that ${ }^{238} \mathrm{U}$ has been replaced by ${ }^{226} \mathrm{Ra}$, a decay product of ${ }^{238} \mathrm{U}$, because ${ }^{238} \mathrm{U}$ and ${ }^{226} \mathrm{Ra}$ may not be in equilibrium.

Three spectra were collected for each of RGK-1, RGU-1 and RGTh-1 standard samples with counting time of $4 \times 10^{4} \mathrm{~s}$ each. Three spectral windows were adjusted around the $1460.8,1764.5$ and $2614.6 \mathrm{keV}$ energy peaks belonging to ${ }^{40} \mathrm{~K}$, ${ }^{214} \mathrm{Bi}$ and ${ }^{208} \mathrm{Tl}$ respectively. The background was collected for a time that was about 10 times the sample collection period (IAEA, 1992).

From the measurements with RGK-1, RGU-1 and RGTh- 1 standards, the ${ }^{40} \mathrm{~K}$, ${ }^{226} \mathrm{Ra}$ and ${ }^{232} \mathrm{Th}$ window count rates, $N_{\mathrm{K}}, N_{\mathrm{Ra}}$ and $N_{\mathrm{Th}}$, are linearly related respectively to the ${ }^{40} \mathrm{~K},{ }^{226} \mathrm{Ra}$ and ${ }^{232} \mathrm{Th}$ concentrations in standards, $C_{\mathrm{K}}, C_{\mathrm{Ra}}$ and $C_{\mathrm{Th}}$. The equations are (Grasty, 1979; IAEA, 1991; IAEA, 1992):

$$
\begin{aligned}
& N_{\mathrm{K}}=A_{\mathrm{K} \cdot \mathrm{K}} C_{\mathrm{K}}+A_{\mathrm{K} \cdot \mathrm{Ra}} C_{\mathrm{Ra}}+A_{\mathrm{K} \cdot \mathrm{Th}} C_{\mathrm{Th}}+B_{\mathrm{K}} \\
& N_{\mathrm{Ra}}=A_{\mathrm{Ra} \cdot \mathrm{K}} C_{\mathrm{K}}+A_{\mathrm{Ra} \cdot \mathrm{Ra}} C_{\mathrm{Ra}}+A_{\mathrm{Ra} \cdot \mathrm{Th}} C_{\mathrm{Th}}+B_{\mathrm{Ra}} \\
& N_{\mathrm{Th}}=A_{\mathrm{Th} . \mathrm{K}} C_{\mathrm{K}}+A_{\mathrm{Th} \cdot \mathrm{Ra}} C_{\mathrm{Ra}}+A_{\mathrm{Th} . \mathrm{Th}} C_{\mathrm{Th}}+B_{\mathrm{Th}}
\end{aligned}
$$

The IAEA has made available a set of radiometric reference material called the "RG set" for the calibration of laboratory gamma ray spectrometers. This set, comprising RGU-1, RGTh-1 and RGK-1 include $500 \mathrm{~g}$ of each (lAEA, 1995). 


\section{TABLE I}

Specific activities, radium equivalent activity, and external and internal hazard indices for the marble samples studied.

Activités spécifiques, activité en équivalent radium, indices de risque externe et interne.

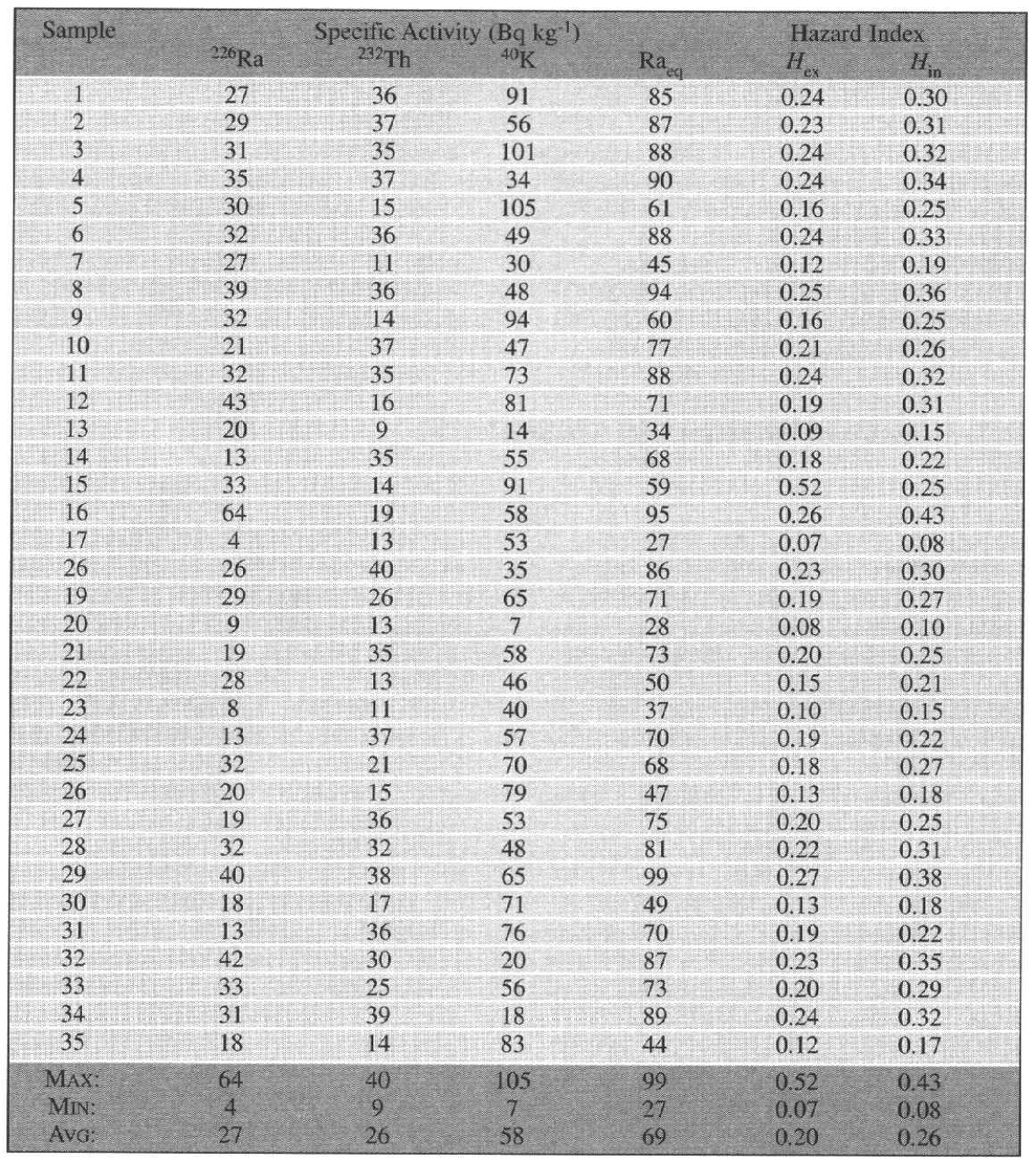

where $B_{\mathrm{K}}, B_{\mathrm{Ra}}$ and $B_{\mathrm{Th}}$ are the background count rates for the ${ }^{40} \mathrm{~K},{ }^{226} \mathrm{Ra}$ and ${ }^{232} \mathrm{Th}$ windows respectively. $A_{i j}$ is the calibration coefficient (IAEA, 1992) representing the contribution count rate in the $i$ th window due to $j$ th standard. Simultaneous solution of these equations yields values of $C_{\mathrm{k}}, C_{\mathrm{Ra}}$ and $C_{\mathrm{Th}}$. This calibration procedure is also called spectrum stripping. 
For each sample, the radium equivalent activity $\left(\mathrm{C}_{\mathrm{Ra}_{\mathrm{cu}}}\right)$ was found using the following relation (Beretka and Mathew, 1985):

$$
C_{\mathrm{Ra}_{\mathrm{iq}}}=C_{\mathrm{Ra}}+\frac{10}{7} C_{\mathrm{Th}}+\frac{10}{130} C_{\mathrm{K}} .
$$

In the above relation for the radium equivalent activity, it has been assumed that $10 \mathrm{~Bq} \mathrm{~kg}{ }^{-1}$ of ${ }^{226} \mathrm{Ra}, 7 \mathrm{~Bq} \mathrm{~kg}{ }^{-1}$ of ${ }^{232} \mathrm{Th}$ and $130 \mathrm{~Bq} \mathrm{~kg}^{-1}$ of ${ }^{40} \mathrm{~K}$ produce equal gamma ray counts (Beretka and Mathew, 1985; Mirza et al., 1992).

Both the gamma rays emanating from the samples and radon pose a health hazard and are usually given in terms of the external $\left(H_{\mathrm{ex}}\right)$ and the internal $\left(H_{\mathrm{in}}\right)$ hazard indices respectively (Beretka and Mathew, 1985; Tufail et al, 1993):

$$
\begin{aligned}
& H_{\text {ex }}=\frac{C_{\mathrm{Ra}}}{370}+\frac{C_{\mathrm{Th}}}{259}+\frac{C_{\mathrm{K}}}{4810} \\
& H_{\text {in }}=\frac{C_{\mathrm{Ra}}}{185}+\frac{C_{\mathrm{Th}}}{259}+\frac{C_{\mathrm{K}}}{4810} .
\end{aligned}
$$

For safe use of a material in the construction of dwellings, $H_{\text {in }}$ should be less than unity (Beretka and Mathew, 1985; Tufail et al., 1993).

A computer program was written for the determination of the specific activities of ${ }^{40} \mathrm{~K},{ }^{226} \mathrm{Ra}$ and ${ }^{232} \mathrm{Th}$, radium equivalent activity, overall absorbed dose rate, external and internal hazard indices.

\section{Results and discussion}

The measured values of the specific activities of the marble samples varied from 4 to $64 \mathrm{~Bq} \mathrm{~kg}^{-1}$ for ${ }^{226} \mathrm{Ra}$, from 9 to $40 \mathrm{~Bq} \mathrm{~kg}^{-1}$ for ${ }^{232} \mathrm{Th}$ and from 7 to $105 \mathrm{~Bq} \mathrm{~kg}^{-1}$ for ${ }^{40} \mathrm{~K}$ as shown in Table $\mathrm{I}$.

For the marble samples studied, the radium equivalent activity ranging from 27 to $99 \mathrm{~Bq} \mathrm{~kg}^{-1}$ was observed, as shown in Table I. Frequency distribution of the measured specific activities of the 35 samples studied is shown in Figure 1. The ${ }^{226} \mathrm{Ra}$ samples show the least variation from class to class in this figure. The distribution of radium equivalent activity, $C_{\mathrm{Ra}_{\mathrm{a} y}}$, is close to the normal distribution.

For the marble samples studied, the calculated values of the internal hazard index have been found to lie in the $0.08-0.43$ range, as shown in Table $I$. The frequency distribution of $H_{\mathrm{ex}}$ peaks at the higher end while that of $H_{\mathrm{in}}$ shifts towards the lower 
M. TUFAIL et al.
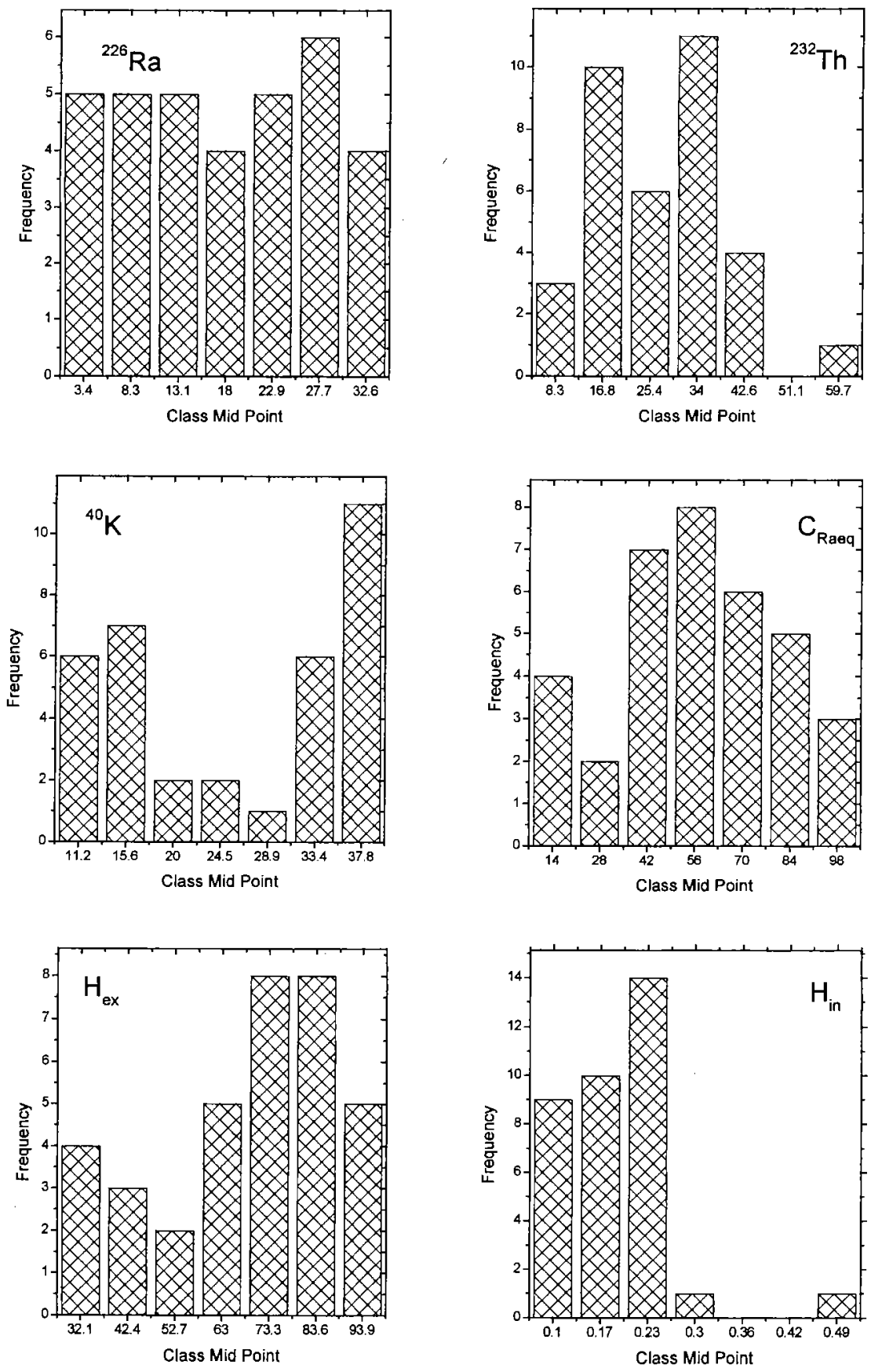
end, as shown in Figure 1. A similar trend is also exhibited by the corresponding minimum, maximum and average values in Table I.

Due to uniformly distributed activity of ${ }^{226} \mathrm{Ra},{ }^{232} \mathrm{Th}$ and ${ }^{4(1)} \mathrm{K}$, the gamma ray exposure rate in air at one meter above an infinitely thick slab is given by (Venturini and Nisti, 1997):

$$
\dot{X}=1.9 C_{\text {Ra }}+2.82 C_{\text {Th }}+0.179 C_{\mathrm{K}}
$$

where, $\dot{X}$ is the exposure rate $\left(\mu \mathrm{R} \mathrm{h}^{-1}\right)$, the activity concentrations $(C)$ are given in pCi. $\mathrm{kg}^{-1}$. The constants on the right hand side of Equation (7) are related to the average gamma ray energies for each radionuclide or series. Using the SI units for the absorbed dose, $8.7 \mathrm{mGy} \mathrm{R}^{-1}$, and for activity, $\mathrm{Bq}$, the estimated absorbed dose rate in air, $\mathrm{nGy}^{-1}$, due to gamma radiation is (Venturini and Nisti, 1997):

$$
D=0.446 C_{\mathrm{Ra}}+0.662 C_{\mathrm{Th}}+0.048 C_{\mathrm{K}}
$$

where the activity concentrations $(C)$ are given in $\mathrm{Bq} \mathrm{kg}^{-1}$. By using the experimentally determined values of $C_{\mathrm{Ra}}, C_{\mathrm{Th}}$ and $C_{\mathrm{K}}$ of Table 1 , in Equation (8), the values of the overall absorbed dose rate for different samples are found to vary from 8 to 60 $\mathrm{nGy} \mathrm{h}^{-1}$. This is the dose contributed by the ground composed of marble rocks.

To calculate the absorbed dose rate at any point from an arbitrary volumetric source of a given shape either a Monte Carlo (MC) simulation of photon histories (Koblinger, 1978) or an evaluation of a volume integral over the source shape can be used (Stranden, 1984; Mirza et al., 1991; Métivier and Kaul, 1998). The simplest approach is to use the MC simulations. However, this method generally requires long computer times, proper choice of pseudo-sources and pseudo-collision laws. In the volume integral method, standard shielding procedures are employed and it typically requires shorter computational time. Mirza et al. (1991) have developed a computer program named INGRE which is based on the volume integral method. In order to enhance its computational speed, a new adaptive technique has been developed in this program. It may be noted that this program calculates the exposure rates due to ${ }^{226} \mathrm{Ra},{ }^{232} \mathrm{Th}$ and ${ }^{40} \mathrm{~K}$ in three separate executions. A comparison of component-wise values of the specific dose rates for the standard room is given in Table II as reported in various studies.

The specific dose rate $\left(\mathrm{nGy} \mathrm{h}^{-1}\right.$ per $\mathrm{Bq} \mathrm{kg}{ }^{-1}$ ) was calculated using the INGRE program for a room constructed from marble. The floor was taken as a volumetric source of thickness $50 \mathrm{~cm}$ composed of a $7 \mathrm{~cm}$ thick marble slab and gravel aggregate below it. The dose point was taken at one meter from the floor surface.

Fig. 1. - The frequency of the measured values of specific activities due to ${ }^{226} \mathrm{Ra},{ }^{232} \mathrm{Th}$ and ${ }^{40} \mathrm{~K}$, the radium equivalent activity, and of the external and internal hazard indices for marble samples. Distribution en fréquence des valeurs mesurées des activités spécifiques dues à ${ }^{226}{ }^{2 a},{ }^{232} \mathrm{Th}$ et ${ }^{40} \mathrm{~K}$, de l'activité en équivalent radium, et des indices de risque externe et interne, pour des échantillons de marbre. 
TABLE II

Values of the specific dose rates $\left(\mathrm{nGy} \mathrm{h}^{-1} / \mathrm{Bq} \mathrm{kg}^{-1}\right)$ for the standard room. Valeurs des débits de dose spécifique $\left(\mathrm{nGy} \mathrm{h} \mathbf{h}^{-1} / \mathrm{Bq} \mathrm{kg}^{-1}\right)$ pour la pièce de référence.

\begin{tabular}{|c|c|c|c|c|}
\hline \multirow[t]{2}{*}{ Method } & \multicolumn{3}{|c|}{ Specific Dose Rate $\left(n G y h^{-1} / \mathrm{Bq}^{-1}\right)$} & \multirow[t]{2}{*}{ Reference } \\
\hline & ${ }^{40} \mathrm{~K}$ & ${ }^{226} \mathrm{Ra}$ & ${ }^{232} \mathrm{Th}$ & \\
\hline Koblinger & 0.09 & 1.05 & 1.18 & (Koblinger, 1978) \\
\hline Mirza et al. & 0.1 & 1.2 & 1.29 & (Mirza et al., 1991) \\
\hline Stranden & 0.09 & 1.05 & 1.27 & (Stranden, 1984) \\
\hline
\end{tabular}

The results of the corresponding dose rates obtained by using the INGRE program are shown in Table III. The dose rate is found to vary from 27 to $108 \mathrm{nGy} \mathrm{h}^{-1}$.

The annual effective dose rate $\dot{E}\left(\mathrm{mSv} \mathrm{y}^{-1}\right)$ can be calculated using the following relation (Tufail et al., 1994):

$$
\dot{E}=T Q \dot{D} \times 10^{-6}
$$

where $10^{-6}$ is the factor converting nano- into milli-, and $\dot{D}$ the absorbed dose rate in air $\left(n G y \mathrm{~h}^{-1}\right), T$ being 8760 hours per year and $Q$ the value of the quotient of the effective dose rate and absorbed dose rate in air as given in UNSCEAR (1988) is $0.7 \mathrm{~Sv} \mathrm{~Gy}^{-1}$. The annual effective dose rate, $\dot{E}$, in air is calculated by substituting the values of $\dot{D}$ in Equation (9).

Table IV gives a comparison of the average values of the whole body dose equivalent rate obtained in this work for a standard room constructed of marble with corresponding values reported in worldwide studies for concrete as building material. Here, it may be noted that the density of concrete and the values of mass attenuation coefficients are close to the corresponding values for marble. The values obtained in the current study for marble are found to lie towards the bottom of this list. A similar trend is also seen when the corresponding values of indoor gamma dose rate are compared with the internationally reported values for concrete in Table IV. The indoor gamma dose equivalent rate lies towards the bottom of this list.

A comparison of the internationally reported values of dose equivalent rate for marbles of different countries of world, is given in Table V. The values for Pakistan marble are the lowest in this international list and slightly higher than the corresponding world average value.

The ICRP (1991) recommendations of the individual dose limit for radiation workers averaged over 5 years is $100 \mathrm{mSv}$ and for members of the general public it is $1 \mathrm{mSv}$ per year. Considering the results, the use of Pakistani marble as a construction material is perfectly safe in terms of radiation exposure and hazards because the calculated dose is far lower than the recommended limits. 
RADIATION DOSES DUE TO NATURAL RADIOACTIVITY IN PAKISTAN MARBLE

TABLE III

Computed values of dose rate using the INGRE code (Mirza et al., 1991, 1992) for various radionuclides.

Valeurs du débit de dose calculées au moyen du code INGRE

(Mirza et al., 1991, 1992) pour divers radionucléides.

\begin{tabular}{|c|c|c|c|c|}
\hline \multirow[t]{2}{*}{ Sample } & \multicolumn{4}{|c|}{ Dose Rate $\left(\mathrm{nGy} \mathrm{h}^{-1}\right)$} \\
\hline & ${ }^{226} \mathrm{Ra}$ & ${ }^{232} \mathrm{Th}$ & ${ }^{40} \mathrm{~K}$ & Total \\
\hline 1 & 32 & 46 & 9 & 87 \\
\hline 2 & 35 & 48 & 6 & 89 \\
\hline 3 & 37 & 45 & 10 & 92 \\
\hline 4 & 42 & 48 & 3 & 93 \\
\hline 5 & 36 & 19 & 11 & 66 \\
\hline 6 & 38 & 46 & 5 & 89 \\
\hline 7 & 32 & 14 & 3 & 49 \\
\hline 8 & 47 & 46 & 5 & 98 \\
\hline 9 & 38 & 18 & 9 & 65 \\
\hline 10 & 25 & 48 & 5 & 78 \\
\hline 11 & 38 & 45 & 7 & 90 \\
\hline 12 & 52 & 21 & 8 & 81 \\
\hline 13 & 24 & 12 & 1 & 37 \\
\hline 14 & 16 & 45 & 6 & 67 \\
\hline 15 & 40 & 18 & 9 & 67 \\
\hline 16 & 77 & 25 & 6 & 108 \\
\hline 17 & 5 & 17 & 5 & 27 \\
\hline 26 & 31 & 52 & 4 & 87 \\
\hline 19 & 35 & 34 & 7 & 76 \\
\hline 20 & 11 & 17 & 1 & 29 \\
\hline 21 & 23 & 45 & 6 & 74 \\
\hline 22 & 34 & 17 & 5 & 56 \\
\hline 23 & 10 & 14 & 4 & 28 \\
\hline 24 & 16 & 48 & 6 & 70 \\
\hline 25 & 38 & 27 & 7 & 72 \\
\hline 26 & 24 & 19 & 8 & 51 \\
\hline 27 & 23 & 46 & 5 & 74 \\
\hline 28 & 38 & 41 & 5 & 84 \\
\hline 29 & 48 & 49 & 7 & 104 \\
\hline 30 & 22 & 22 & 7 & 51 \\
\hline 31 & 16 & 46 & 8 & 70 \\
\hline 32 & 50 & 39 & 2 & 91 \\
\hline 33 & 40 & 32 & 6 & 78 \\
\hline 34 & 37 & 50 & 2 & 89 \\
\hline 35 & 22 & 18 & 8 & 48 \\
\hline MAX: & 77 & 52 & 11 & 108 \\
\hline MiN: & 5 & 12 & 1 & 27 \\
\hline Avo: & 32 & 34 & 6 & 72 \\
\hline
\end{tabular}


TABLE IV

Comparison between the indoor gamma dose rates within a reference room constructed of concrete from different countries and Pakistan marble.

Valeurs comparées des débits de dose gamma à l'intérieur de la pièce de référence.

\begin{tabular}{|c|c|c|c|c|c|c|}
\hline Country & $\begin{array}{l}\text { Specific } \\
226 \mathrm{Ra}\end{array}$ & ${ }^{232} \mathrm{Th}$ & $\begin{array}{c}(\mathrm{Bq} \mathrm{kg-1}) \\
{ }^{40} \mathrm{~K}\end{array}$ & $\begin{array}{l}\text { Total dose } \\
\text { rate } \\
\left(\mathbf{n G y} \mathbf{h}^{-1}\right)\end{array}$ & $\begin{array}{l}\text { Dose equiv. } \\
\text { rate } \\
\left.\text { (mSv year }{ }^{-1}\right)\end{array}$ & References \\
\hline Australia & 14.8 & 40.7 & 199.8 & 90 & 0.55 & $\begin{array}{l}\text { (Beretka and Mathew, } \\
\text { 1985) }\end{array}$ \\
\hline Finland & 53 & 37 & 840 & 195 & 1.20 & (Mustonen, 1984) \\
\hline Germany & 30.7 & 24.1 & 458 & 114 & 0.70 & $\begin{array}{l}\text { (Ettenhuber and } \\
\text { Lehmann, 1986) }\end{array}$ \\
\hline Italy & 19 & 24.2 & 457 & 100 & 0.61 & (Battaglia, et al., 1985) \\
\hline Netherlands & 15 & 16 & 130 & 52 & 0.32 & (Ackers et al., 1985) \\
\hline Norway & 28 & 36 & 650 & 145 & 0.90 & $\begin{array}{l}\text { (Stranden and Berteig, } \\
\text { 1980) }\end{array}$ \\
\hline Sweden & 47 & 80 & 577 & 217 & 1.33 & (Mjones, 1986) \\
\hline USA & 22 & 11 & 350 & 76 & 0.46 & (Parades et al., 1987) \\
\hline Malaysia & 85.1 & 51.8 & 321.8 & 201 & 1.23 & $\begin{array}{l}\text { (Chong and Ahmad, } \\
\text { 1982) }\end{array}$ \\
\hline Present Work & 27 & 26 & 58 & 72 & 0.44 & \\
\hline
\end{tabular}

Note: The present work is based on marble while the others are based on concrete.

TABLE V

Comparison between the indoor gamma dose rates due to marble alone (this work) and internationally reported values for various construction materials.

Comparaison des débits de dose gamma à l'intérieur, dus au marbre seul (notre travail), aux valeurs publiées au niveau international pour divers matériaux de construction.

\begin{tabular}{|lcl|}
\hline Country & $\begin{array}{c}\text { Effective dose equivalent } \\
\left.\text { rate (mSv year }{ }^{-1}\right)\end{array}$ & \multicolumn{1}{c|}{ Reference } \\
\hline Germany & 0.51 & (Ettenhuber and Lehmann, 1986) \\
Hong Kong & 0.95 & $($ Ng et al., 1995) \\
Kenya & 0.47 & (Mustapha et al., 1997) \\
$\begin{array}{l}\text { World Average } \\
\text { (weighted) }\end{array}$ & 0.34 & (UNSCEAR, 1988) \\
\hline Pakistan & 0.44 & Present study (Marble) \\
\hline
\end{tabular}

\section{Conclusions}

The measured average values of the specific activities, in marble, due to ${ }^{226} \mathrm{Ra},{ }^{232} \mathrm{Th}$ and ${ }^{40} \mathrm{~K}$ have been found to be between 4-64, 9-40 and 7-105 $\mathrm{Bq} \mathrm{kg}^{-1}$ respectively. For the samples studied in this work, the average values of the radium equivalent activity $\left(\mathrm{Bq} \mathrm{kg}^{-1}\right)$, the external and the internal hazard indices are $69,0.20$ and 0.26 respectively. Using the INGRE code, the average specific dose rates $\left(\mathrm{nGy} \mathrm{h}^{-1}\right)$ in a marble-finished standard room due to ${ }^{40} \mathrm{~K},{ }^{232} \mathrm{Th}$ and ${ }^{226} \mathrm{Ra}$ activity have been 
estimated at 6,34 and 32. The average values of the over-all absorbed dose rates and the dose equivalent rates in air have been found to be $72 \mathrm{nGy} \mathrm{h}^{-1}$ and $0.44 \mathrm{mSv}^{-1}$ respectively. The values of both the specific activities and the whole body dose rates due to ${ }^{40} \mathrm{~K},{ }^{232} \mathrm{Th}$ and ${ }^{226} \mathrm{Ra}$ natural activity in marble samples collected from Pakistan are below the maximum permissible limits set by various international organizations. We, therefore, conclude that marble available in Pakistan can safely be used as a construction material for dwellings.

\section{REFERENCES}

Ackers J.G., Den-Boer J.F., De-Jong P., Wolschrijn R.A. (1985) Radioactivity and radon exhalation rates of building materials in the Netherlands, Sci. Total Environ. 45, 151-156.

Ahmad Z. (1969) Directory of mineral deposits of Pakistan. Records of the Geological Survey of Pakistan, Vol. 15, part 3, pp. 176-177.

Aslam, Ahmad N. (1997) Indoor specific dose rates in Jordanian dwellings to natural radioactivity in construction materials. Pakistan institute of engineering and applied sciences, P.O. Nilore, lslamabad 45650, Pakistan, Report CNS-344.

Beretka J.. Mathew P.J. (1985) Natural radioactivity of Australian building materials, waste and byproducts, Health Phys. 48, 87-95.

Battaglia A., Bazzano E., Bonfanti G. (1985) Indoor dose in Milano (Italy), Sci. Total Environ. 45, 365 371.

Chong C.S., Ahmad G.U. (1982) Gamma activity of some building material in West Malaysia, Health Phys. 43, 272-273.

Ettenhuber E., Lehmann R. (1986) The effective dose equivalent due to the naturally occurring radionuclides in building materials in the German Democratic Republic. Part 1: External exposure, Health Phys. 50 (1), 49-56.

Grasty R.L. (1979) Gamma ray spectrometric methods in uranium exploration-Theory and operational procedures. In: Geophysics and Geochemistry in the search of metallic ores (Hood P.J., Ed.) pp. 147-161. Geological Survey of Canada, Economic Geology Report $n^{\circ} 31$.

IAEA (1991) Airborne gamma ray spectrometer surveying. Technical Reports Series $\mathrm{n}^{\circ} 323$, Vienna.

IAEA (1992) Analytical techniques in uranium exploration and ore processing. Technical Reports Series $n^{\circ} 34-1$, Vienna.

IAEA (1994) International basic safety standards for protection against ionizing radiation and for the safety of radiation sources. Safety Series $n^{\circ} 1$ 15-1, Vienna.

IAEA (1995) Analytical quality control services. Intercomparison runs reference materials, G4.12, Vienna.

ICRP Publication 60 (1991) Radiation Protection: 1990 Recommendations of the International Commission on Radiological Protection, Amn. ICRP 21 ( $1-3$ ).

ICRP Publication 65 (1993) Protection against ${ }^{222} \mathrm{Rn}$ at home and at work, Ann. ICRP 23 (2).

Jamil K., Al-Ahmady K.K., Rehman F., Ali S., Qureshi A.A., Khan H.A. (1997) Relative performance of different types of passive dosimeters employing solid state nuclear track detectors, Health Phys. 73, 629-632.

Koblinger L. (1978) Calculation of exposure rates from gamma sources in walls of dwelling rooms, Health Phys. 34, 459.

Métivier H., Kaul A. (1998) Intake of radionuclides, Radiat. Prot. Dosim. 79 (1-4), 115-118.

Mirza N.M., Ali B., Mirza S.M., Tufail M., Ahmad N. (1991) A shape and mesh adaptive computational methodology for gamma ray dose from volumetric sources, Radiat. Prot. Dosim. 38, 307-314.

Mirza N.M., Ahmad N., Mirza S.M., Tufail M. (1992) Assessment of cancer risk due to radioactivity in construction materials. Pakistan Institute of Engineering and Applied Sciences, P.O. Nilore, Islamabad 45650, Pakistan, Report CNS-27.

Mjones L. (1986) Gamma radiation in Swedish dwellings, Radiat. Prot. Dosim. 15 (2) 131-140. 
Mustapha A.O., Narayana D.G.S., Patel J.P., Otwoma D. (1997) Natural radioactivity in some building materials in Kenya and the contributions to the indoor external doses, Radiat. Prot. Dosim. 71 (1), $65-69$.

Mustonen, R. (1984) Method for evaluation of radiation from building materials, Radiat. Prot. Dosim. 7, 235-238

Ng C.Y., Leung J.K.C., Tso M.Y.W. (1995) Modeling exposure to naturally occurring radionuclides in building materials, Radiat. Prot. Dosim. 59 (1), 43-48.

NRPB (1981) The work of National radiological protection board 1977/80 and review of the first 10 years. Chilton, Didcot, Oxfordshire OX11 0RQ. ISBN 0-85951-160-Z.

Parades C.H., Kessler W.V., Landolt R.R., Zeemer P.L., Paustenbach D.I., (1987) Radionuclide content of and ${ }^{222} \mathrm{Rn}$ emanation from building materials, made from phosphate industry waste product, Heallh Phys. 53, 23-29.

Shah S.M.I. (1977) Stratigraphy of Pakistan. Memoirs of Geological Survey of Pakistan, Vol. 12, Geological Survey of Pakistan.

Stranden E. (1984) Radioactivity in building materials and the gamma-radiation in dwellings, Phys. Med. Biol. 24, $921-930$.

Stranden E., Berteig L. (1980) Radon in dwellings and influencing factors, Health Phys. 39, $275-284$.

Tufail M., Ahmad N., Mirza S.M., Mirza N.M., Khan H.A. (1992a) Natural radioactivity from the building materials used in Islamabad and Rawalpindi, Pakistan, Sci. Total Environ. 121, $283-291$.

Tufail M., Ahmad N., Mirza S.M., Mirza N.M., Sarwar S.M., Zafar M.S. (1992b) Natural radioactivity in cements manufactured by various factories of Pakistan, Nucl. Geophys. 6 (4), 553-559.

Tufail M. (1992c) Radon and gamma activity measurements for determination of radiation doses, assessment of cancer risks and applications to geology/geophysics. Ph.D. Thesis, Department of Physics, University of the Punjab, Lahore, Pakistan.

Tufail M., Ahmad N., Zafar M.S., Siddiqui M.S., Sarwar M.S., Ali S., Almakky S. (1993) Gamma activity in Lahore: Pakistani building materials, Arabian J. Sci. Eng. 18 (3) 353-363.

Tufail M., Rashid T., Mahmood A.B., Ahmad N. (1994) Radiation doses in Pakistani houses, Sci. Total Environ. 142, 171-177.

UNSCEAR (1988) Sources, effects and risks of ionization radiation. 1988 Report to the general assembly with annexes, New York, USA.

Venturini L., Nisti M.B. (1997) Natural radioactivity of some Brazilian building materials, Radiat. Prot. Dosim. 71 (3), 227-229.

WHO (World Health Organization) (1993) Working group summary report. WHO Doc. ICP / CEH $109(\mathrm{~S})$. 